\title{
Reinstatement of Gymnosporia (Celastraceae): implications for the Flora Malesiana region
}

\author{
Marie Jordaan and A.E. van Wyk
}

\begin{abstract}
Jordaan, Marie ${ }^{1}$ and van Wyk, A.E. ${ }^{2}\left(^{1}\right.$ National Botanical Institute, Private Bag X101, Pretoria, Republic of South Africa 0001; e-mail: marie@nbipre.nbi.ac.za; ${ }^{2}$ Department of Botany, University of Pretoria, Pretoria, Republic of South Africa 0002; e-mail: avanwyk@postino.up.ac.za) 2003. Reinstatement of Gymnosporia (Celastraceae): implications for the Flora Malesiana region. Telopea 10(1): 155-167. The reinstatement of the genus Gymnosporia, comprising all the spiny members previously included in the genus Maytenus, has implications for the Flora Malesiana region. An account is given of six species and two varieties in the region (Gymnosporia curtisii, G. diversifolia, G. inermis, G. littoralis, G. nitida, G. spinosa var. spinosa and var. parva). The new combination G. littoralis (Backer) Jordaan is made (based on Gymnosporia montana var. littoralis) and a neotype and lectotype designated for two other taxa. G. emarginata from India and Sri Lanka is also included since this name was previously misapplied to plants in the Flora Malesiana region. Maytenus rapakir is mentioned as probably belonging to Gymnosporia. Maytenus cupularis, which has a racemose inflorescence, is related to the Australian species of Maytenus s. lat. and is retained in Maytenus.
\end{abstract}

\section{Introduction}

The Celastraceae account for the Flora Malesiana was published by Ding Hou in 1962 and 1964. His genus concepts coincide with those of Exell (1952, 1953), Blakelock (1956), Marais (1960) and Robson $(1965,1966$ \& 1994) in that he considers Gymnosporia and Maytenus to be congeneric. New research on the family suggests that larger genera need to be recircumscribed into smaller segregate ones. The genus Gymnosporia (Wight \& Arn.) Hook.f. has recently been reinstated (Jordaan \& Van Wyk 1999, Archer \& Jordaan 2000) to include all its spiny members, previously placed under Maytenus Molina sens. lat. A study of Gymnosporia (the southern African species) was undertaken and the subdivision of the genus into eight sections was proposed (Jordaan 1995), based mainly on fruit and seed morphology as well as leaf anatomy; a monographic study covering the genus on a worldwide basis is currently in progress. All the Gymnosporia species in the Flora Malesiana region have seed with a basal aril and are placed in G. section Tenuispina M.Jordaan ined. Diagnostic characters of Gymnoporia include the presence of brachyblasts and spines, leaves which are in fascicles or alternate, the inflorescence which is a dichasium, the flowers which are mostly functionally unisexual, the fruit which is a dehiscent capsule and the seeds which have an aril.

Gymnosporia is an Old World genus of suffrutices, shrubs and trees. It comprises about 108 members, occurring in the whole of Africa, Madagascar and adjacent islands, southern Spain, the near Middle East, Afghanistan, Pakistan, India, Sri Lanka, Thailand, Vietnam, S China, Taiwan, Ryukyu Islands (Japan), Malesia, and Queensland (Australia), with G. vitiensis (A.Gray) Seem. endemic to the Polynesian Islands.

The genus has two main centres of diversity on the Afro-Arabian continent: (i) NE tropical Africa and tropical Arabia and (ii) southern Africa. There is a high degree of regional endemism at both specific and sectional level and there are only a few 
widespread species in the genus. Five members of Gymnosporia occur on the Philippines, which is the highest level of species diversity in the Flora Malesiana region. The purpose of this contribution is to provide an account of the members of Gymnosporia native to the Flora Malesiana region.

\section{Taxonomy}

\section{Key to the species}

1a Plants with spines of two kinds: axillary ones and lateral branches ending in a spine:

2a Capsules 2-valved:

3a Leaves usually smaller than $30 \mathrm{~mm}$; China, Taiwan, Ruykyu Islands and N Philippines 6. G. diversifolia

3b Leaves usually longer than $30 \mathrm{~mm}$; Thailand, Malaysia and Java 5. G. littoralis

2b Capsules 3-valved:

4a Plants totally glabrous; India and Sri Lanka

7. G. emarginata

$4 \mathrm{~b}$ Plants with puberulous or muricate branches; Thailand, Malaysia and Java

5. G. littoralis

$1 \mathrm{~b}$ Plants usually without spines or when spines present then only axillary ones, lateral branches not ending in a spine:

5a Pericarp of capsules thick $( \pm 1.5 \mathrm{~mm})$, woody

4. G. nitida

$5 \mathrm{~b}$ Pericarp of capsules thin, papery (less than $1 \mathrm{~mm}$ ):

6a Leaf apex acute to short-acuminate; Thailand and Malaysia

3. G. curtisii

$6 \mathrm{~b}$ Leaf apex obtuse, rounded to emarginate; Taiwan, Philippines, Indonesia, New Guinea, Australia:

7a Brachyblasts usually present; leaves coriaceous; capsules longer than $6 \mathrm{~mm}$ 1. G. inermis

$7 \mathrm{~b}$ Brachyblasts usually absent; leaves membranous; capsules shorter than $6 \mathrm{~mm}$ 2. G. spinosa

\section{Gymnosporia inermis Merrill \& Perry}

(Merrill \& Perry 1939: 335).

Type: Papua New Guinea: Western Division: Tarara, Wassi Kussa River, Brass 8690, Jan 1937; holo A; iso L!, LAE!, US!

Gymnosporia montana sensu Benth.

(Bentham 1863: 400), non M.A.Lawson (M.A.Lawson 1875: 621).

Maytenus emarginata sensu Ding Hou

(Ding Hou 1962: 241), quoad specimens from N Queensland, Philippines, Celebes, Moluccas and New Guinea; sensu Jessup (Jessup 1984: 164).

Scandent shrub or small tree, up to $5 \mathrm{~m}$ high, glabrous in all parts, with spines when young, becoming spineless with age; brachyblasts well developed on older branches; branches angular when young, grey, with inconspicuous lenticels. Leaves alternate on young branchlets, fasciculate on older ones, ovate, elliptic or oblong, (30-)40-110(-140) 
$\times(15-) 20-76(-110) \mathrm{mm}$, apex rotundate to retuse, or subacute to emarginate, base cuneate to rotund, margin distinctly crenulate-serrate, reticulate venation prominent on both sides; petioles up to $12 \mathrm{~mm}$ long, sometimes pinkish-tinged. Inflorescence axillary, solitary or few-flowered in short cymes; peduncle $\pm 10 \mathrm{~mm}$ long, pink-tinged; pedicels up to $4 \mathrm{~mm}$ long, pink-tinged, bracts lanceolate. Flowers white or creamcoloured, 5-7(-9) $\mathrm{mm}$ in diameter, fragrant. Sepals semi-orbiculate. Petals oblongovate, $2-3(-4) \times 1-2 \mathrm{~mm}$, apex obtuse, margin fimbriate. Male flowers: stamens slightly shorter than petals; pistillode short; stigmas absent. Disc green, 5-lobed. Female flowers: staminodes shorter than stamens of male flowers: ovary 3-locular, green; style as long as ovary, 3-branched. Capsule 3-valved, obconic-trigonous, 3-angled, 6-12 mm long, green becoming red. Seed ellipsoid, glossy, 3.5-5.5 $\times 2-4 \mathrm{~mm}$; aril reddish, reduced to a basal rim. (Fig. 1).

Diagnostic characters: plants when young with spines, but spines not developing on older stems; well developed brachyblasts present; leaves coriaceous and losing spines with age; well developed brachyblasts present; leaves coriaceous and usually longer than $40 \mathrm{~mm}$, apex rounded, obtuse to emarginate or subacute; capsules 3-valved, red; seed with a basal aril.

Distribution and ecology: (Celebes and Moluccas) Indonesia, New Guinea, East Coast of the Philippines, Taiwan and Queensland (Australia). Growing at elevations from near sea level and locally abundant on the coast on sand at the edge of mangrove forest, or secondary forest, at forest margins, in thickets on beaches and hillsides and on sea cliffs, often on limestone.

Selected specimens examined: INDONESIA: Kei Island (Kai Kecil), Jensen 80, 25 Mar 1922 (GH, L); Tanimbar Islands: Selaru, Namtabung, Van Borssum 3176, 17 Mar 1956 (K, L); Moluccas: Sula Islands, Tandjong Baliha, Bloembergen 4389, 28 July 1939 (GH, SING); Aru Islands: Pulau Trangan, Kp. Kerei, Turner 115, 17 Apr 1993 (GH, L). Sulawesi (Celebes): Tukangbesi, Binongko, Elbert 2559, 23 July 1909 (L).

NEW GUINEA: West Papua: Radjah Ampat, Waigeo Island, Lupintol on SW coast of Majalibit Bay, Van Royen 5454, 8 Feb 1955, (L); Merauke, Koch Expedition 1904-1905 (L).

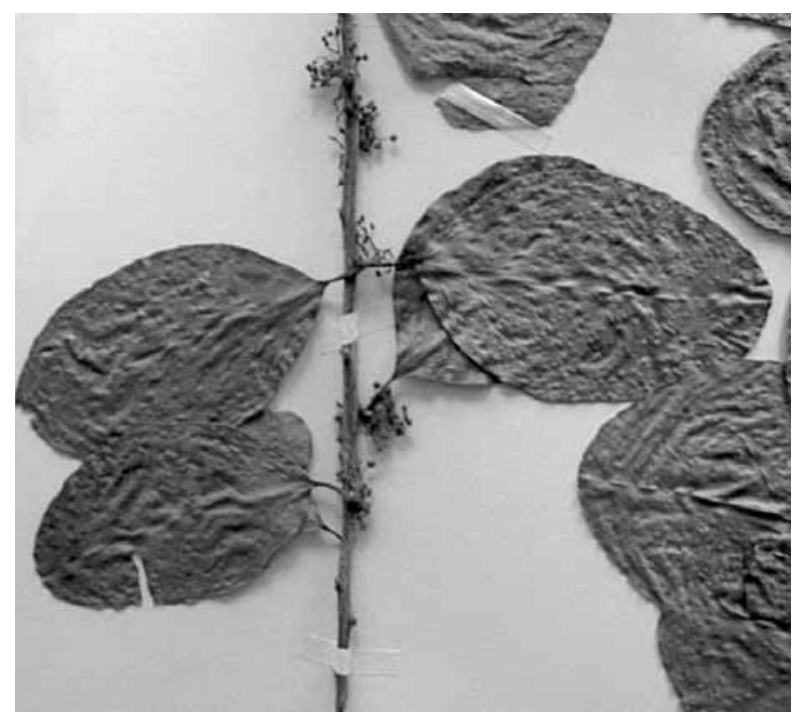

Fig. 1. Gymnosporia inermis. Sulawesi (Celebes): Binongko, Pulau, Elbert 2559 (L). 
Papua New Guinea: Tarara, Wassi Kussa River, Brass 8690, Jan 1937 (L, LAE, US); Lea Lea, NW of Pt. Moresby, Pullen 3359, 19 July 1962 (CANB, LAE); Daru Island, Brass 622929 Mar 1936 (L); Nanuk Island, East New Britian Prov., Nagari UPNG 7303, 3 Nov 1981 (LAE).

PHILIPPINES: Dalupiri Island: Babuyan Group, $1^{\circ} 10^{\prime} \mathrm{N} 121^{\circ} 15^{\prime} \mathrm{E}$, Bartlett 15075, 15168, 31 Oct5 Nov 1935 (GH); Luzon: Isabela Prov: Palanan municipality, Dipoduanaw Point, $17^{\circ} 06.8^{\prime} \mathrm{N}$ 122 31.1'E, Leonardo Co 3393, 3394, 18 Apr 1991 (GH, K, L, PNH); Luzon: Sierra Madre Mountains of Dingalan, sea level, $15^{\circ} 29^{\prime} \mathrm{N} 121^{\circ} 23^{\prime} \mathrm{E}$, Jacobs 7772, 16 Mar 1968 (L).

AUSTRALIA: Queensland: Jack Jacky Ck, Cape York, 10 58' S 142 ${ }^{\circ} 30^{\prime} \mathrm{E}$, Jones 3821, 25 Oct 1965 (CANB); Portland Roads, $12^{\circ} 35^{\prime}$ S $143^{\circ}$ 25' E, Dockrill 468, 4 July 1972 (BRI, K); Cairns: Webb \& Tracey 8193, June 1965 (BRI, CANB).

2. Gymnosporia spinosa (Blanco) Merrill \& Rolfe

(Merrill \& Rolfe 1908: 109); (Merrill 1918: 235); (Loesener 1942: 151).

Cupania spinosa Blanco

(Blanco 1837: 184).

Type: Philippines: Luzon Island: Bulacan Prov., Angat, Merrill: Species Blancoanae 349, Sep 1913; neo US! (designated here); isoneo GH!, L!

var. spinosa

Selected specimens examined: PHILIPPINES: Luzon: Cagayan Prov:: Nabanagan, Pacheco 29523, Mar 1923 (GH); Bulacan Prov.: Angat, Merrill: Species Blancoanae 349, Sep 1913 (L, US); Rizal Prov.: San Juan del Monte, Pr Manila, Vidal 189 (GH); Lubang Islands: Merrill 978, Apr 1903 (GH); Panay: Port Iloilo, Vidal 189, Nov-Dec 1958 (GH).

var. parva Merrill $\mathcal{E}$ Rolfe

(Merrill \& Rolfe 1908: 110).

Type: Philippines: Luzon Island: Rizal Province, Montalban, Mariquina River, Merrill 5070 March 1905; holo PNH†; iso K!, L!, NY! US!

G. philippinensis Vidal (Vidal 1885: 103), nom. nudum quoad specimen Cuming 1575 (L). Rolfe (1886) stated that this is just a manuscript name and not validly published.

Selected specimens examined: PHILIPPINES: Luzon: Cuming 1575 (L); Rizal Prov., Montalban, Elmer 12573, Jan 1910 (GH, L); Merrill 5070, Mar 1905 (K, L, NY, US).

Plants sometimes with small thin axillary spines, even on fruiting branches. A distinct species with two varieties, which can be separated from $G$. inermis by axillary spines more often present, its membranous leaves $(20-35 \times 8-20 \mathrm{~mm})$ which are narrower, more elliptic and thinner. It has 3-valved capsules like G. inermis, but the capsules are smaller, shorter than $5 \mathrm{~mm}$. The difference between the two varieties lies in the size of the leaves; var. parva has smaller leaves, shorter and narrower than $20 \mathrm{~mm}$. (Fig. 2).

Distribution: apparently endemic to the Philippines.

Notes: Merrill and Rolfe (1908) stated, and we agree, that G. spinosa is not the same as G. montana (Roth ex Roem. \& Schult.) M.A.Lawson from India, which is the type species of the genus Gymnosporia.

Merrill and Perry (1939) stated that G. inermis is closely related to G. spinosa but lacks the spines of the latter species. G. inermis and G. spinosa are indeed very closely related. Specimens of G. spinosa var. spinosa and var. parva have often short axillary spines, lack brachyblasts, their leaves are thinner in texture and the reticulate venation on both surfaces of the leaves is more prominently raised than in G. inermis; their capsules are smaller (usually less than $6 \mathrm{~mm}$ long). 
Blanco (1837) originally described G. spinosa in Flora de Filipinas, but apparently there is no original material in PNH of Blanco's names of new taxa. Merrill's specimen at US is therefore selected here as a neotype, following the recommendation of Nicolson and Arculus (2001).

\section{Gymnosporia curtisii King}

(King 1896: 353); (Prain 1904: 198); (Ridley 1922: 451).

Type: Malaysia: Kedah Prov., Polo Tanyury Piri, Curtis 2500, Sep 1890; holo K!

Maytenus curtisii (King) Ding Hou

(Ding Hou 1962: 240).

Illustration: Ding Hou (1962: fig. 2a-d).

Erect or scandent shrub or small tree; spines robust, in axils of leaves. Leaves coriaceous, elliptic, sometimes broadly elliptic, 62-85 $(-110) \times 27-36(-90) \mathrm{mm}$, base cuneate, tapering into petiole, apex acute to short-acuminate, rarely obtuse, margin crenulate, principal lateral veins $7-9(-15)$, obliquely spreading towards margin and curved upwards, reticulate venation obvious above; petiole 5-9 $\mathrm{mm}$ long. Inflorescences cymose, usually crowded towards apex of brachyblasts, axillary, puberulous when young; peduncle $5-10 \mathrm{~mm}$ long; bracts lanceolate, short-fimbriate; pedicels $2-5 \mathrm{~mm}$ long. Flowers white. Sepals deltoid or semi-orbicular, $0.5-0.75 \mathrm{~mm}$ in diameter, margins sparsely ciliate. Petals ovate or obovate-oblong, $2.5-3.2 \times 1.5 \mathrm{~mm}$, obtuse, \pm entire. Disc fleshy, rounded, $1.5-2.0 \mathrm{~mm}$ in diameter. Male flowers with stamens $\pm 2.5 \mathrm{~mm}$ long; anthers broad-ovoid, $0.5 \mathrm{~mm}$ long, slightly apiculate; pistillode with short style, stigmas absent. Female flowers with staminodes very short or abortive; ovary trilocular; style longer than ovary; stigma 3-lobed. Capsule 3-valved, obconic-trigonous, concave at tip, $\pm 15 \times 13 \mathrm{~mm}$. Seed ellipsoid, slightly irregularly rugose, $7-8 \times 4-5 \mathrm{~mm}$; aril \pm flat or shallowly disc-like and attached laterally at base.

Diagnostic characters: plants usually with axillary spines; leaf apex acute to shortacuminate; capsule $15 \mathrm{~mm}$ long, 3-valved; seed with a flat or shallowly disc-like aril, laterally attached at base.

Distribution and ecology: Thailand and Malaysia. It occurs on limestone at sea level, or in lowland forests.

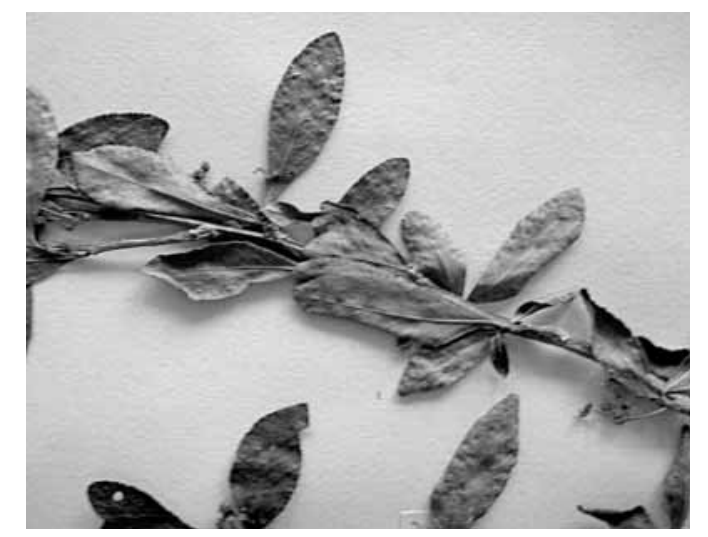

Fig. 2. Gymnosporia spinosa var. parva. Philippines: Rizal Province, Montalban, Elmer 12573 (L). 
Selected specimens examined: THAILAND: Doi Chiengdao, Put 380 (K); Kelantan Prov., Gua Jaya, Jenera, Whitmore FRI4261 (K).

MALAYSIA: Kedah Prov., Polo Tanyury Piri, Curtis 2500 (K); Kedah Prov., Pulau Dayang Bunting, Soepadmo \& Mohmud 1229 (K); Langkawi Island, Selat Panchor, Pulau, Henderson 21368 (K).

\section{Gymnosporia nitida Merrill}

(Merrill 1914: 31), non Maytenus nitida Mart.

Type: Philippines: Luzon Island: Pangasinan Prov., Domingo FB11836, 1912-1913; holo $\mathrm{K!}$; iso L, US!

Maytenus crassa Ding Hou, nom. nov.

(Ding Hou 1962: 242).

Ding Hou (1962) described it as having small, short, axillary spines and said that it occurred in the Philippines, but it was found only once. Gymnosporia nitida has 3valved capsules, but the distinguishing character seems to be the thick pericarp $( \pm 1.5$ $\mathrm{mm}$ ) of the dehiscent fruits.

Specimen examined: PHILIPPINES: Luzon Island: Pangasinan Prov., Domingo FB11836, 1912-1913 (K, US).

5. Gymnosporia littoralis (Backer) Jordaan, comb. et stat. nov.

Gymnosporia montana var. littoralis Backer (Backer 1908: 55; 1911: 235); (Koorders 1912: 524).

Type: Java: Batavia, Tandjong Priok, Backer 34926, Dec 1905; holo BO!

Lax scandent shrub, up to $3 \mathrm{~m}$ high; branches subangular, puberulous, muricate to glabrous, dark brown or pale grey, with lenticels, spinescent; spines glabrous or puberulous, up to $15 \mathrm{~mm}$ long, of two kinds: spines short, axillary and spines terminating short lateral shoots. Leaves fasciculate on brachyblasts, subcoriaceous, glabrous or with few scattered hairs, obovate, oblanceolate, or broad-obovate, $12-60 \times$ 10-20 mm, subcoriaceous, apex obtuse, rounded or emarginate, base attenuate narrowed into the petiole, margin sparsely denticulate or crenulate; petiole up to $4 \mathrm{~mm}$ long, puberulous to glabrous. Inflorescences fasciculate or solitary, axillary or crowded at upper part of a short-shoot, shorter than leaves; peduncles puberulous, $4-6 \mathrm{~mm}$ long; bracts elliptic, short-fimbriate; pedicels 1-6 mm long. Flowers small, greenishwhite. Sepals deltoid or suborbicular, $0.5-0.7 \mathrm{~mm}$ long, margins short fimbriate. Petals oblong or elliptic, obtuse, 1-3 mm long, margin subentire. Disc cupular. Male flowers: stamens $\pm 1.2 \mathrm{~mm}$ long; pistillode flask-like, $\pm 1 \mathrm{~mm}$ long; style very short; stigma obscure. Female flowers: staminodes very small or abortive; ovary subglobose, narrowed into a distinct, 2(3)-branched style. Capsule 2(3)-valved, obconic-trigonous, red, 4-6×5-7 mm. Seeds 2 or 3, ellipsoid, $\pm 3 \times 1.5 \mathrm{~mm}$, smooth and glossy; aril at base. (Figs 3 \& 4).

Diagnostic characters: plants with axillary and/or terminal spines (short lateral branches ends in a spine); stems, spines, petioles and often peduncles puberulous or muricate; leaves glabrous or with few scattered hairs, laxly arranged on stems, obovate-oblong, oblanceolate or broad-obovate, apex obtuse; ovary 2(3)-locular; disc cupular; capsules obconic-trigonous, usually smaller than $6 \mathrm{~mm}$.

Distribution and ecology: S Thailand, Malaysia and Java. It occurs mainly along seashore, in marsh thicket.

Selected specimens examined: THAILAND: 1/4 mile SW of Vayama, Maxwell s. n. L430468, 24 Jan 1969 (L); Samut Sakhon, Ban Khlong Su, Van der Kevie 19, 26 June 1960 (L). MALAYSIA: S Tukong, S Johore, Spare F958 (SING); Pulau Sibu, Johore, June 1991, Wong 101 (SINU). 
JAVA: Batavia, Tandjong Priok, Backer 34926, Dec 1905 (BO); Anjol near Tandjong Priok, Djerro Kotan 85 (L); no precise locality, 16 Oct 1903, Sargent s.n. (GH).

Note: specimens from Malay Peninsula (Johore) and Java determined by Ding Hou as Maytenus emarginata in 1962, belongs to this species.

\section{Gymnosporia diversifolia Maxim.}

(Maximowicz 1881: 459); (Loesener 1941: 149); (Ding Hou 1950: 177).

Type: Japan: Archipelagi Lu-schu Islands (Ryukyu Islands): U-shima, Charles Wright s.n., 1853-1856; holo? NY468032!; iso? US16301.

Celastrus diversifolia (Maxim.) Hemsl.

(Hemsley 1886: 123).

Celastrus buxifolia L. var. subdidymocarpus Kuntze

(Kuntze 1891: 115).

Type: Annam (Vietnam), Bai Turong (Bai Thuong), 24 Feb 1875, Kuntze 3642; lecto NY! (designated here); isolecto $\mathrm{K}$ !

Maytenus diversifolia (Maxim.) Ding Hou

(Ding Hou 1962: 242); (Li 1977: 629); (Lu \& Yang 1993: 654).

Illustration: Li (1977: pl. 754), Lu \& Yang (1993: pl. 338).

Scandent or erect shrub, up to $4 \mathrm{~m}$ high; branches zigzag, puberulous to muricate, spinescent. Spines up to $15 \mathrm{~mm}$ long, of two kinds: spines short, axillary and spines terminating short lateral shoots. Leaves mainly alternate, subcoriaceous; lamina obovate, oblanceolate, or broad-obovate to round, 17-30 × 10-20 (-25) mm, apex obtuse, rounded or emarginate, base attenuate narrowing into the petiole, margin sparsely denticulate or crenulate, or sometimes subentire, principal lateral veins 3 or 4; petiole very short or subsessile. Inflorescences fasciculate or solitary, sometimes 1-flowered, axillary or crowded at upper part of a short-shoot, shorter than the leaves,

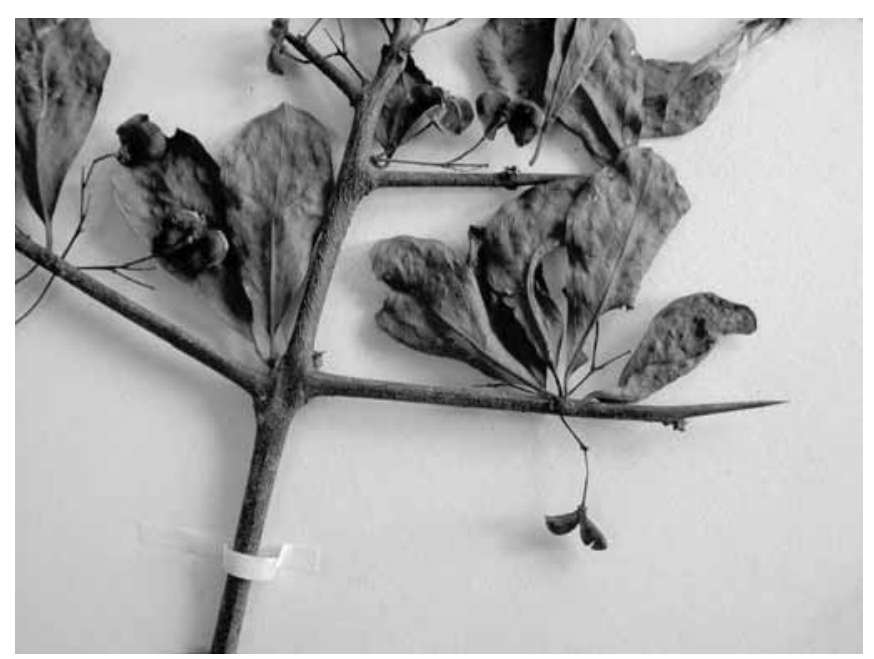

Fig. 3. Gymnosporia littoralis. Thailand: 1/4 mile SW of Vayama, Maxwell s.n. L430469 (L). 
10-20 mm long; peduncles 4-6 mm long; bracts elliptic, short-fimbriate; pedicels 1-4 mm long. Flowers small, greenish white. Sepals deltoid or suborbicular, $0.5-0.7 \mathrm{~mm}$ long, margins short-fimbriate. Petals oblong or elliptic, obtuse, $1-3 \mathrm{~mm}$ long. Disc cupular. Male flowers with stamens $\pm 1.2 \mathrm{~mm}$ long; pistillode flask-like, $\pm 1 \mathrm{~mm}$ long; style very short; stigma obscure. Female flowers: staminodes very small or abortive; ovary subglobose, narrowing into a distinct style, style 2-branched. Capsule 2-valved, compressed-obcordate, \pm inflated, red, $5-6 \times 5-8 \mathrm{~mm}$. Seeds 2 or 3 , ellipsoid, $\pm 3 \times 1.5 \mathrm{~mm}$, smooth and glossy; aril at base.

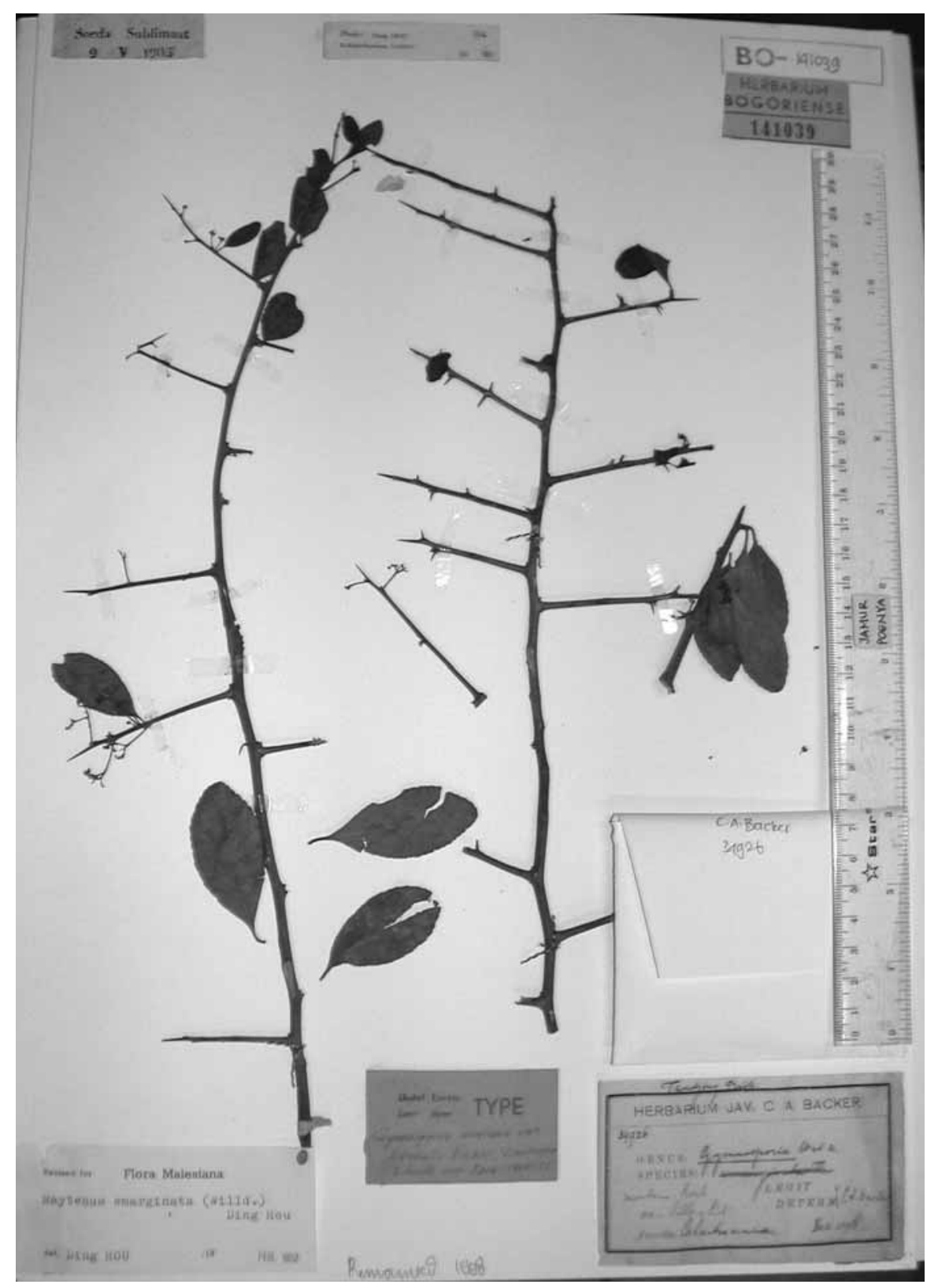

Fig. 4. Gymnosporia littoralis (type). Java: Batavia, Tandjong Priok, Backer 34926 (BO). 
Diagnostic characters: plants with axillary and/or terminal spines (short lateral branches ending in a spine); leaves obovate-oblong, oblanceolate or broadly obovate, apex obtuse; ovary bilocular; disc cupular. Differs from G. inermis in having smaller leaves and 2-valved capsules.

Distribution and habitat: Philippines, Taiwan, S China (Xiamen), Ryukyu Islands (Japan) and Vietnam. It occurs mainly in coral places or dry thickets along the seashore.

Selected specimens examined: PHILIPPINES: Luzon: Ilocos Norte Prov., Burgos, Ramos 27204, Feb-Mar 1917 (GH).

TAIWAN: Kaohsiung, Playfair $271(\mathrm{~K})$.

CHINA: Fukien: Amoy (Xiamen), Ching 777, 1922 (SING).

JAPAN: Ryukyu Islands: S of lighthouse, Fosberg 38585 (K); Loo-Choo Islands (Ryukyu Islands), Wright 53 (K), Wright s.n. (NY468032, US16301).

VIETNAM: Bai Turong (Bai Thuong), Kuntze 3642, 24 Feb 1875 (K, NY).

\section{Gymnosporia emarginata (Willd.) Thwaites}

(Thwaites 1864: 409); (M.A.Lawson 1875: 621); (Loesener 1902: 471); (Loesener 1942: 150). Celastrus emarginatus Willd.

(Willdenow 1798: 1128); (Wight \& Arnott 1834: 160).

Type: Eastern India, B. Heyne s.n. Herb. Willdenow 4752; holo B (microfiche at PRE!).

Catha emarginata (Willd.) Don

(Don 1832: 9); (Walpers 1842: 532).

Maytenus emarginata (Willd.) Ramam.

(Ramamurthy 1983: 74); (Matthew 1995: 85); (Wadhwa 1996: 83); non Ding Hou (1962: 241); non Li (1977: 629); non Jessup (1984: 164); non Lu. \& Yang (1993: 654).

Shrub or small tree up to $6 \mathrm{~m}$ high; bark pale brown, smooth, cracked; branches terete, with pale lenticels; spines axillary or terminating short lateral shoots. Leaves thick, coriaceous, shining above, paler beneath; lamina narrowly lanceolate to obovate, oblanceolate to rotundate, rarely elliptic-oblong, 25-40 $(-70) \times 15-30 \mathrm{~mm}$, apex rounded or obtuse, usually emarginate, margin thickened, usually entire or remotely crenate in distal part, reticulate venation usually obscure above, prominent below; petiole short, 1-3 $\mathrm{mm}$ long. Inflorescence axillary, often on spines, few-flowered; peduncle short, 1.0-2.5 mm long; pedicel very slender, glabrous, 7-9 mm long. Flowers pale greenish-yellow or white, sweet-scented, $\pm 4 \mathrm{~mm}$ in diam. Sepals deltoid, $\pm 1 \mathrm{~mm}$ long, apex obtuse, margin ciliate. Petals obovate-oblong or oblong, 2-3 $\times 1.0-1.5 \mathrm{~mm}$, twice as long as sepals, apex subacute, often reflexed, margin entire or uneven. Disc very broad, fleshy, sinuate-lobed. Male flowers: stamens slightly shorter than petals, inserted slightly beneath the disc margin; anthers broadly ovoid; pistillode globose, small, style unbranched. Female flowers: staminodes shorter than stamens in male flowers; ovary semi-immersed in disc, 3-locular; style cylindrical, 3-branched, spreading. Capsule obconic-trigonous, inflated, flat-topped, apiculate, 3-valved, 3-5 $\times$ 6-12 mm, red or dull purple. Seed ovoid or ellipsoid, red and shining, 2.5-3.5 × 2.0-2.5 $\mathrm{mm}$; aril white, fleshy, a basal rim. (Fig. 5).

Distribution and habitat: S India and Sri Lanka. Growing in scrub, on coastal plains, up to $500 \mathrm{~m}$.

Diagnostic characters: leaf apex is usually emarginate, margin is entire or only remotely crenate in the distal part; peduncles short (up to $2 \mathrm{~mm}$ long) and pedicels 
long and slender (up to $9 \mathrm{~mm}$ ), which is unusual for this genus (usually with long peduncles and short pedicels); capsule 3-valved.

Note: this name is now considered to apply only to plants from India and Sri Lanka. The name is therefore misapplied to plants in the Flora Malesiana region. Specimens previously named Maytenus emarginata by Ding Hou in 1962, occurring in Malesia (Philippines, Celebes, Moluccas and New Guinea) and northern Queensland in Australia now belong to Gymnosporia inermis.

Selected specimens examined: INDIA: South Arcot: Ulundurpet, $4 \mathrm{~km}$ to Pulloorkkadu, Matthew \& Perumal RHT 20070, 12 Dec 1978 (L, RHT); Vallampadugai, Ramamurthy 90458, 16 Mar 1989 (BSI).

SRI LANKA: Northern Province: Jaffna District, SE Point Pedro, near Kaddaikadu, Bernardi 14253, 16 Mar 1973 (L); Central Province: Matale District, Laggala, altitude \pm 900 m, Cramer 5005, 25 Nov 1977 (K); Central Province: Peradeniya Botanic Garden, 7 16' N $80^{\circ}$ 37’ E, Kostermans 27823, 3 Oct $1979(\mathrm{~K})$.

\section{Maytenus rapakir Loes.}

(Loesener 1936: 217); Loesener 1942: 140)

Type: Bismarck Archipelago (New Ireland): Neu-Mecklenburg, Namatanai, Peekel 433, flowers and fruits in May; (holo B, probably destroyed).

Leaves ovate, papery, 85-130 long. Inflorescence cymose, many-flowered. Capsules 3-valved, 7-8 $\mathrm{mm}$ long and seed with basal aril.

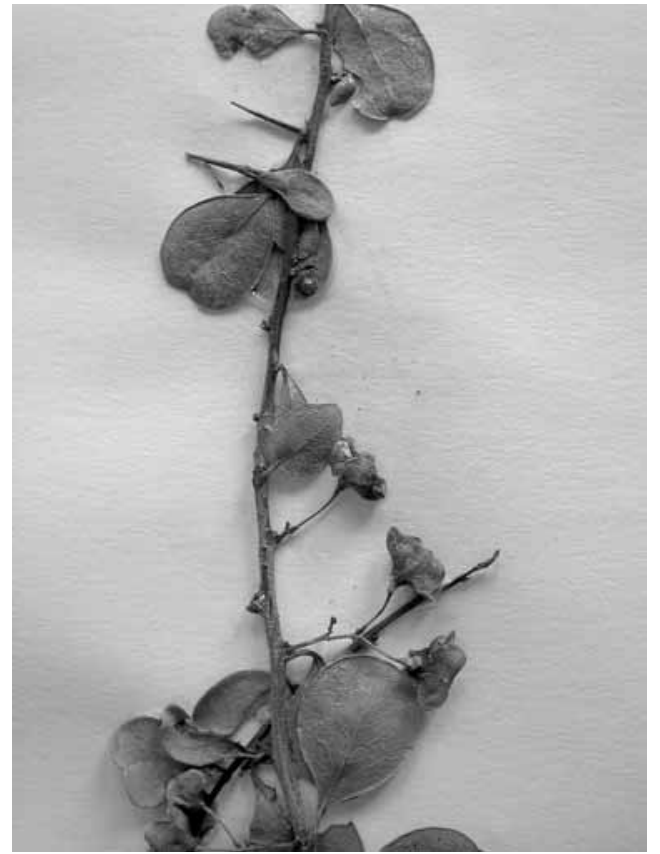

Fig. 5. Gymnosporia emarginata. Sri Lanka: Matale District, Laggala, Cramer 5005 (K). 
Note: Ding Hou (1962) mentioned this name and said that it is distinct because of the broadly ovate-oblong to ovate leaves. Loesener (1936) when he described this species placed it in Maytenus section Fasciculatae and noted that the flowers appeared to be unisexual, thus suggesting that it may be an intermediate between the genera Maytenus and Gymnosporia. However, according to the description (large ovate to oblong leaves and cymose inflorescences), it agrees with Gymnosporia and also fits into its overall distribution pattern; it seems to be close to G. inermis and G. vitiensis (A.Gray) Seem.

Sleumer (1960) mentioned that most of Peekel's type specimens collected in the Bismarck Archipelago, which he sent to Berlin Herbarium, were destroyed during World War II. 'Rapakir' is probably a native name added to the generic name, as was Peekel's custom. The authors of this paper were unsuccessful in tracing any duplicates of the type material or other authentic material of this species.

\section{Maytenus cupularis Ding Hou}

(Ding Hou 1962: 243).

This species has a racemose inflorescence and has a cupular disc and is related to the Australian members of Maytenus s. str. All the Gymnosporia species in this region are spiny shrubs, up to $5 \mathrm{~m}$ high, growing near sea level at the edge of mangroves or along the seashore, whereas this species is a $30 \mathrm{~m}$ rainforest tree.

\section{Conclusions}

As currently circumscribed, the genus Maytenus Molina, even after the reinstatement of Gymnosporia (Jordaan \& Van Wyk 1999), is still clearly a heterogeneous assemblage which will have to be split into more natural genera, a view also supported by Rogers et al. (1999), Simmons \& Hedin (1999), Simmons et al. (2001a) and Simmons et al. (2001b). Species remaining in Maytenus do not have spines and their leaves are always alternate, not fascicled, their inflorescence type varies from racemose, fascicled to monochasial cymes and their flowers are bisexual. The Celastraceae of the Flora Malesiana region needs revision, especially at the generic level. There are six species and two varieties of Gymnosporia, and one species of Maytenus s.lat, in this region.

\section{Acknowledgments}

The authors are grateful to the keepers of the following herbaria for the loan of specimens: BRI, CANB, GH, K, L, LAE, SING, SINU, US. We also want to thank Dan Nicolson (US) and Dr Irawati from the Bogor Herbarium for their kind assistance in finding the Merrill and Backer type specimens and literature.

\section{References}

Archer, R.H. \& Jordaan, M. (2000) Celastraceae in O.A. Leistner (ed.), Seed Plants of Southern Africa: families and genera. Strelitzia 10: 214-220.

Backer, C.A. (1907) Celastraceae in Flora van Batavia, vol. 1. (G. Kolff \& Co.: Batavia).

Backer, C.A. (1908) Celastraceae in Voorloper eener schoolflora voor Java. (Visser \& Co.: Weltevreden).

Backer, C.A. (1911) Celastraceae in Schoolflora voor Java. (Visser \& Co.: Weltevreden).

Bentham, G. (1863) Celastrineae in Flora australiensis, vol. 1. (L. Reeve \& Co.: London).

Blanco, F.M. (1837) Flora de Filipinas. (D. Candido Lopez: Manila).

Blakelock, R.A. (1956) Notes on African Celastraceae. Kew Bulletin 11: 237-244.

Ding Hou. (1950) Celastraceae in Taiwania 1: 177. 
Ding Hou. (1962) Celastraceae. Pp 227-291 in C.G.G.J. van Steenis (ed.), Flora Malesiana ser. 1, vol. 6 (2). (Noordhoff: Groningen).

Ding Hou. (1964) Celastraceae. Pp 389-421 in C.G.G.J. van Steenis (ed.), Flora Malesiana ser. 1, vol. 6 (2). (Noordhoff: Groningen).

Don, G. (1832) Celastrineae in A general system of gardening and botany, vol. 2. (Rivington: London).

Exell, W.A. (1952) Novidades da flora de Angola. Boletim da Sociedade Broteriana, sér. 2, vol. 26: 221-235.

Exell, W.A. (1953) Tropical African plants: XXIII. Celastraceae. Kew Bulletin 1953: 103, 104.

Hemsley, W.B. (1886) An enumeration of all the plants known from China Proper, Formosa, Hainan, Corea, the Luchu Archipelago, and the Island of Hongkong. Celastrineae. Journal of the Linnean Society, Botany 23: 118-125.

Jessup, L.W. (1984) Celastraceae in Flora of Australia, vol. 22. (AGPS: Canberra).

Jordaan, M. (1995) A taxonomic revision of the spiny members of subfamily Celastroideae (Celastraceae) in southern Africa. Unpublished M.Sc. thesis, University of Pretoria.

Jordaan, M. \& Van Wyk, A.E. (1999) Systematic studies in subfamily Celastroideae (Celastraceae) in southern Africa: reinstatement of the genus Gymnosporia. South African Journal of Botany 65: 177-181.

King, G. (1896) Materials for a Flora of the Malayan Peninsula. Gymnosporia in Journal of the Asiatic Society of Bengal 65: 353, 354.

Koorders, S.H. (1912) Celastraceae in Exkursionsflora von Java, vol. 2. (Verlag von Gustav Fischer: Jena).

Kuntze, C.E.O. (1891) Celastraceae in Revisio generum plantarum 1: 113-117. (Arthur Felix: Leipzig).

Lawson, M.A. (1875) Celastrineae. Pp. 606-629 in J.D. Hooker (ed.), Flora of British India vol. 1 (3). (L. Reeve \& Co.: London).

Li, H-L. (1977) Celastraceae. Pp. 628-633 in Flora of Taiwan, vol. 3. (Epoch Publishing Co.: Taiwan).

Loesener, L.E.T. (1902) Übersicht über die bis jetzt bekannten chinesischen Celastraceen. Botanische Jahrbücher 30: 446-474.

Loesener, L.E.T. (1936) Celastraceae novae vel melius cognoscendae II. Botanischen Notizblatt des Botanischen Gartens und Museums zu Berlin-Dahlem 13: 215-226.

Loesener, L.E.T. (1942) Celastraceae. Pp. 87-158 in A. Engler \& K. Prantl (eds.), Die natürlichen Pflanzenfamilien edn 2, vol. 20b. (Duncker \& Humblot: Berlin).

Lu, S.-Y. \& Yang, Y.-P. (1993). Celastraceae. Pp. 640-660 in Flora of Taiwan, ed. 2, vol. 3. (National Science Council of the Republic of China: Taiwan).

Marais, W. (1960) An enumeration of the Maytenus species of southern Africa. Bothalia 7: 381-386.

Matthew, K.M. (1995) Celastraceae. Pp. 83-85 in An excursion flora of central Tamilnadu, India, reprint edition. (Oxford \& IBH Publishing Co.: Calcutta).

Maximowicz, C.J. (1881) Diagnoses plantarum novarum asiaticarum. Bulletin de l'académie impèriale des sciences de Saint-Pétersbourg 27: 459.

Merrill, E.D. (1914) Celastraceae in Philippine Journal of Science 9: 31.

Merrill, E.D. (1918) Species blancoanae: a critical revision of the Philippine species of plants described by Blanco and by Llanos. Bureau of Science Publication 12: 1-423.

Merrill, E.D. \& Perry, L.M. (1939) Plantae Papuanae Archboldianae. Journal of the Arnold Arboretum 20: 324-345.

Merrill, E.D. \& Rolfe, R.A. (1908) Notes on Philippine Botany. Celastraceae. Philippine Journal of Science 3: 109, 110.

Nicolson, D.H. \& Arculus D. (2001) Candidates for neotypification of Blanco's names of Philippine plants: specimens in the U.S. National Herbarium. Taxon 50: 947-954.

Prain, D. (1904) Bengal Plants (Calcutta).

Ramamurthy, K. (1983) Celastraceae in Nair \& Henry (eds.), Flora Tamilnadu, vol. 1: 74.

Ridley, H.N. (1922) Celastrineae. Pp. 443-461 in The Flora of the Malay Peninsula, vol. 1. (L. Reeve \& Co.: London).

Robson, N.K.B. (1965) New and little known species from the Flora zambesiaca area xvi. Boletim da Sociedade Broteriana, sér. 2, vol. 39: 6-25.

Robson, N.K.B. (1966) Celastraceae. Pp. 355-418 in A.W. Exell \& H. Wild (eds.), Flora zambesiaca, vol. 2. (Crown Agents: London).

Robson, N.K.B. (1994) Celastraceae, Maytenus. Pp. 1-21 in R.M. Polhill (ed.), Flora of tropical East Africa, Celastraceae. (Balkema: Rotterdam).

Rogers, C.B., Abbott, A.T.D. \& van Wyk, A.E. (1999) A convenient thin layer chromatographic technique for chemotaxonomic application in Maytenus (Celastraceae). South African Journal of Botany 65: 174-176. 
Rolfe, R.A. (1886) Cuming's Philippine plants. Journal of Botany 24: 57-60.

Simmons, M.P. \& Hedin, J.P. (1999) Relationships and morphological character change among genera of Celastraceae sensu lato (including Hippocrateaceae). Annals of the Missouri Botanical Gardens 86: 723-757.

Simmons, M.P., Clevinger, C.C., Savolainen, V., Archer, R.H., Mathews, S. \& Doyle, J.J. (2001a) Phylogeny of the Celastraceae inferred from phytochrome B gene sequence and morphology. American Journal of Botany 88: 313-325.

Simmons, M. P., Savolainen, V., Clevinger, C.C., Archer, R.H. \& Davis, J.I. (2001b) Phylogeny of the Celastraceae inferred from 26S nrDNA, phytochrome B, $a t p B, r b c L$, and morphology. Molecular Phylogenetics and Evolution 19: 353-366.

Sleumer, H. (1960) Flora of Bismarck Archipelago. Taxon 9: 90.

Thwaites, G.H.K. (1864) Enumeration plantarum zeylaniae (Dulau: London).

Vidal, S.S. (1885) Phanerogamae Cumingiana Philippinarum (Manila).

Wadhwa, B.M. (1996) Celastraceae. Pp. 75-106 in M.D. Dassanayake \& W.D. Clayton (eds.), A Revised Handbook to the Flora of Ceylon, vol. 10. (Balkema: Rotterdam).

Walpers, W.G. (1842) Celastrineae. Repertorium botanices systematicae 1: 532-534.

Wight, R. \& Arnott, G.A.W. (1834) Prodromus florae peninsulae Indiae orientalis 1: 159-160.

Willdenow, C.L. (1798) Species plantarum, Caroli a Linné 1. Edn 4. (Berlin). 
